\title{
Growth of extremely low birth weight infants at a tertiary hospital in a middle-income country
}

\author{
Tendai Mabhandi ${ }^{*}$, Tanusha Ramdin and Daynia Elizabeth Ballot
}

\begin{abstract}
Background: Survival of extremely low birth weight (ELBW; birth weight less than $1000 \mathrm{~g}$ ) infants has improved significantly since the 1990s. Consequently, growth monitoring in ELBW infants has gained more relevance.

Methods: We conducted this study to describe the growth of ELBW infants at a tertiary hospital, to audit macronutrient intake and explore the association of prematurity complications with growth. This was a retrospective study on 92 ELBW infants born at Charlotte Maxeke Johannesburg Academic Hospital. The association between good growth (regaining birth weight in 21 days or less and subsequent growth velocity $>15 \mathrm{~g} / \mathrm{kg} /$ day) and complications of prematurity was explored.

Results: Only 11 infants (13\%) had a discharge weight above the 10th centile when the Fenton growth chart was used compared to 20 infants (22.4\%) when the Intergrowth 21st Project growth standard was used. The mean weight velocity was $13.5 \mathrm{~g} / \mathrm{kg} /$ day and the mean number of days to regain birth weight was 18.2 days. Factors associated with poor growth were late-onset sepsis, persistent patent ductus arteriosus, continuous positive airway pressure for more than 2 days, invasive ventilation, oxygen on day 28 and being kept nil per os. Protein and caloric intake correlate positively with growth velocity. Unlike the Fenton Growth Charts, use of the Intergrowth 21st Project growth standards revealed the association between neonatal factors and poor growth.

Conclusion: Growth outcome in infants is poor at 36 weeks postmenstrual age at our institution. Intergrowth 21st Project growth standards were superior to Fenton Growth Charts, however a multicentre study is required before adoption.
\end{abstract}

Keywords: Extremely low birth weight, Neonate, Growth, Nutrition

\section{Background}

Survival of extremely low birth weight (ELBW) infants has improved significantly since the 1990s owing to advances in obstetric and neonatal care [1]. Consequently, growth monitoring of ELBW infants has gained more interest. Poor growth among ELBW infants has been well documented [2]. Although ELBW infants have compensatory growth into their early adult years, they remain shorter than their predicted mid-parental heights [3]. Low birth weight infants have also been noted to have a poor neurocognitive outcome [4]. There is growing evidence among ELBW infants that inadequate nutrition during the early weeks of life leads to persistent growth faltering that may lead to

\footnotetext{
* Correspondence: Tendai.Mabhandi@students.wits.ac.za Johannesburg, South Africa
}

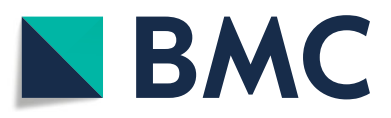

(c) The Author(s). 2019 Open Access This article is distributed under the terms of the Creative Commons Attribution 4.0 International License (http://creativecommons.org/licenses/by/4.0/), which permits unrestricted use, distribution, and reproduction in any medium, provided you give appropriate credit to the original author(s) and the source, provide a link to the Creative Commons license, and indicate if changes were made. The Creative Commons Public Domain Dedication waiver (http://creativecommons.org/publicdomain/zero/1.0/) applies to the data made available in this article, unless otherwise stated. infants showed that increas the first week of life was associated with a better neurodevelopmental outcome at 18 months [6].

Nutrition in ELBW infants is surrounded by several challenges. In a low resource setting, ITN (Intravenous Total Nutrition) may not be readily available due to cost limitations [7]. Furthermore, difficult venous access, suspected or established diagnosis of necrotizing enterocolitis (NEC), sepsis and metabolic derangements frequently interfere with ITN and enteral feeds administration $[8,9]$.

There is little information in South Africa on the growth of ELBW infants and their caloric intake while in hospital. A previous prospective study on very low birth 
weight (VLBW) infants admitted at Charlotte Maxeke Johannesburg Academic Hospital (CMJAH) showed that infants had initial poor growth followed by catch-up growth but with persistent deficits at 20 months [10]. Another study at CMJAH concluded that VLBW infants had a weight velocity approaching recommended values [11]. A study conducted in Cape Town on ELBW infants showed that weight velocity was approaching the generally accepted standard [12], however, weight Z-score and macronutrient intake were not described in the study. Therefore, the present study aimed to review growth and audit macronutrient intake of ELBW infants in the setting of a tertiary hospital.

\section{Methods}

Aim

This was a pilot study to review the growth of ELBW infants at CMJAH from birth to 36 weeks postmenstrual age, audit their macronutrient intake and explore the association of prematurity complications with growth.

\section{Study design}

The study was a retrospective longitudinal description of growth and macronutrient intake in ELBW infants at CMJAH.

\section{Participant characteristics Inclusion criteria}

All ELBW infants admitted at CMJAH within $72 \mathrm{~h}$ of birth between 01 January 2015 and 31 March 2017 were included in the study.

\section{Exclusion criteria}

Infants who were transferred to other hospitals or demised before discharge, those with chromosomal abnormalities and major congenital abnormalities were excluded.

\section{Study process}

The study was a secondary analysis of an existing database managed using Research Electronic Data Capture (REDCAP), hosted by the University of Witwatersrand [13] and a review of relevant hospital records. Weight was captured weekly until discharge. The volume of feeds, intravenous (IV) fluids and ITN was captured daily for the first 28 days of life. The number of days to regain birth weight was captured and the mean weight velocity was calculated from the day birth weight was regained to 36 weeks postmenstrual age. Mean weight velocity was calculated using the exponential method [14] as shown below;

$$
\begin{aligned}
& \text { Weight velocity } \\
& =1000 \mathrm{X} \ln \left(\text { Weight }^{36 \text { weeks }} / \text { Weight }{ }^{\text {Birth weight regained }}\right) / \text { Time interval }
\end{aligned}
$$

The Fenton's Growth Chart [15] and Intergrowth 21st Project growth standards $[16,17]$ were used as reference for normal growth. For the Intergrowth 21st Project growth standards, the Intergrowth 21st Project newborn charts were used to derive the birth weight Z-scores and the Intergrowth 21st Project postnatal growth charts were used to derive the Z-scores at 36 weeks. An infant born with a birth weight below the 10th centile was referred to as small for gestational age (SGA) [18]. The delta Z-score from birth to 36 weeks postmenstrual age was determined for each infant. To avoid underrepresentation of infants with good growth, infants discharged before 36 weeks postmenstrual age had their discharge weight Z-score analyzed as that at 36 weeks. Delta Z-score was calculated using the formula below;

$$
\begin{aligned}
\text { Delta } \mathrm{Z} \text {-score } & =\text { Weight } \mathrm{Z} \text {-score at } 36 \text { weeks } \\
& - \text { Weight Z-score at birth }
\end{aligned}
$$

For the purpose of computation of macronutrients, the nutritional content of the various types of feeds, IV fluids and ITN was derived from product inserts and previous studies (Table 1) [19]. Daily caloric intake in $\mathrm{kcal} / \mathrm{kg} /$ day was calculated for each infant during the first 28 days for life using the formula below, where volume is in milliliters (mls), weight in grams and the figure 1000 converts grams to kilograms;

$$
\begin{aligned}
& \text { Daily caloric intake } \\
& =\frac{1000 \mathrm{X} \text { Volume }}{\text { Current heaviest weight }}
\end{aligned}
$$

Mean weekly caloric intake for each week and mean caloric intake over 28 days was calculated. A mean caloric intake of at least $110 \mathrm{kcal} / \mathrm{kg} /$ day was classified as good caloric intake. Daily protein and lipid intake were calculated using a similar formula to the daily caloric intake.

Definitions of complications of prematurity were based on those used in the Vermont Oxford Network (www. vtoxford.org). The need for ventilation (invasive and non-invasive), as well as complications of prematurity including NEC, retinopathy of prematurity (ROP), late onset sepsis ( $>72 \mathrm{~h}$ after birth), oxygen on day 28 of life and patent ductus arteriosus (PDA) were recorded. Necrotizing enterocolitis and PDA were defined in this study as follows;

- NEC was defined as NEC grade 2 or 3 according to modified Bells' staging [20]

- ROP was defined as stage 2 or more [21] 
Table 1 Daily infant nutritional requirements and nutritional composition of feeds and parenteral nutrition

\begin{tabular}{|c|c|c|c|c|c|c|c|c|}
\hline & $\begin{array}{l}\text { Daily infant Requirement (per } \\
\text { kg weight) }\end{array}$ & $\begin{array}{l}\text { Neonatolyte } \\
\text { (per dL) }\end{array}$ & $\begin{array}{l}\text { ITN } 101 \\
\text { per dL }\end{array}$ & $\begin{array}{l}\text { ITN } 102 \\
\text { per dL }\end{array}$ & $\begin{array}{l}\text { ITN } 105 \\
\text { per dL }\end{array}$ & $\begin{array}{l}\text { Breastmilk } \\
\text { per dL }\end{array}$ & $\begin{array}{l}\text { Prenan } \\
\text { per dL }\end{array}$ & $\begin{array}{l}\text { Breastmilk Fortifier } \\
\text { (FM85) (per } 1 \mathrm{~g})\end{array}$ \\
\hline $\begin{array}{l}\text { Energy } \\
\text { (kcal) }\end{array}$ & $105-130$ & 40 & 38.3 & 62.4 & 46.2 & 67 & 80 & 4.4 \\
\hline $\begin{array}{l}\text { Dextrose } \\
\text { (g) }\end{array}$ & - & 10 & 9.57 & 10.41 & 6.3 & - & - & - \\
\hline $\begin{array}{l}\text { Protein } \\
\text { (g) }\end{array}$ & $3.5-4.5 \mathrm{~g}$ & 0 & 1.91 & 2.08 & 2.1 & 1.0 & 2.3 & 0.4 \\
\hline Lipid (g) & $5-7 g$ & 0 & 0 & 2.08 & 2.1 & 3.5 & 4.2 & 0.2 \\
\hline
\end{tabular}

- PDA was defined as a hemodynamically significant PDA on echocardiography [22]

\section{CMJAH neonatal unit}

The unit's feeding protocol was as follows: Prescription of feeds was at the discretion of the attending physician. Although exclusive breastfeeding was unit protocol, no donor breast milk was available. Hence, the infant formula Prenan (Nestle) was provided for those ELBW infants whose mothers were unwilling or unable to breastfeed. Newly born infants were started on intravenous fluids (usually Non-K Neonatolyte) at 80 to $100 \mathrm{mls} / \mathrm{kg} /$ day on the first day of life. Feeds were introduced on the second day of life starting at $20 \mathrm{mls} / \mathrm{kg} /$ day. Feeds were gradually increased by 20 to $30 \mathrm{mls} / \mathrm{kg} /$ day replacing intravenous fluids until 160 to $180 \mathrm{mls} / \mathrm{kg} /$ day of full enteral feeds was reached. Upon reaching full enteral feeds, each feed of breastmilk was fortified with $1 \mathrm{~g}$ FM85 (Nestle). Enteral feeds were discontinued if there was evidence of feeding intolerance. Infants who were not on full feeds for more than $48 \mathrm{~h}$ due to any reason had ITN prescribed for them provided no contraindications to ITN administration were present. Infants were weighed twice a week on an electronic scale (NAGATA BW-20, Taiwan). In the absence of ongoing complications requiring hospital care, infants were discharged upon attaining $1600 \mathrm{~g}$. Infants with respiratory distress syndrome (RDS) were offered nasal continuous positive airway pressure (NCPAP) and surfactant. Upon delivery, infants with RDS were transferred to a Transitional Unit where they were offered NCPAP if available. This was done while the infant awaited transfer to their final destination, the Premature Unit, where NCPAP was usually available.

\section{Statistical analysis}

Data was entered into a Microsoft Excel Spreadsheet for data cleaning. The final dataset was exported into IBM SPSS 25 for analysis. The distribution of continuous variables was explored. Those variables with a normal distribution were described using mean and standard deviation (SD) while those with a skewed distribution were described using median and interquartile range
(IQR). Categorical variables were described by frequencies and percentages.

An infant with good growth was defined as that infant who regained birth weight in 21 days or less and had a weight velocity of at least $15 \mathrm{~g} / \mathrm{kg} /$ day $[23,24]$. An infant with poor growth was defined as that infant who regained birth weight after 21 days and/or had a growth velocity less than $15 \mathrm{~g} / \mathrm{kg} /$ day. The association of growth with complications of prematurity was assessed in three ways as follows;

- Comparison of occurrence of prematurity complications between infants with good and those with poor growth.

- Comparison of the occurrence of prematurity complications between infants who attained a weight above 10th centile at 36 weeks and those who failed to attain such a weight.

- Delta Z-scores from birth to 36 weeks were analyzed as a continuous variable.

For continuous variables, student t-test was used for variables with normal distribution and Mann Whitney U-test for ranked data or those variables with a skewed distribution. The Chi-squared test of independence was used for categorical variables.

\section{Results}

\section{Sample characteristics}

There were 2829 infants with birth weight less than $1500 \mathrm{~g}$ infants captured on the database. Of these, 886 were ELBW infants. After excluding those outside the study period, 325 infants remained. Ten infants were transferred to other hospitals and 181 infants died in hospital. Therefore, 134 infants were eligible for the study. Forty-two infants had missing records leaving a final sample of 92 . For derivation of weight Z-scores and centiles, 89 were included because 3 infants had a gestational age less than 24 weeks and therefore could not be plotted on the Intergrowth 21st Project newborn charts. Characteristics of the sampled infants are displayed in Table 2. 
Table 2 Characteristics of sample population

\begin{tabular}{ll}
\hline & $N=92$ \\
\hline Baseline characteristics & \\
Females, frequency (percentage) & $47(51.1 \%)$ \\
Birth weight in grams, mean (SD) & $867(81.4)$ \\
Birth weight Z -score, mean (SD) & $0.4(1.1)$ \\
Gestational age at delivery in weeks, mean (SD) & $27.6(2.0)$ \\
Duration of hospital stay in days, mean (SD) & $69.1(17.1)$ \\
Postmenstrual age at discharge in weeks, mean (SD) & $36.7(2.7)$ \\
Kangaroo care, frequency (percentage) & $46(50.0 \%)$ \\
Predominantly breastfed at discharge & $49(52.3 \%)$ \\
Prenatal factors & $2(2.2 \%)$ \\
Chorioamnionitis, frequency (percentage) & $51(55.4 \%)$ \\
Antenatal steroids, frequency (percentage) & \\
Postnatal complications & $13(14.1 \%)$ \\
Patent dictus arteriosus, frequency (percentage) & $53(57.6 \%)$ \\
Sepsis after day 3 of life, frequency (percentage) & $17(18.5 \%)$ \\
Invasive ventilation, frequency (percentage) & $29(31.5 \%)$ \\
Continuous positive airway pressure for more & $61(66.3 \%)$ \\
than 2 days, frequency (percentage) & $79(85.7 \%)$ \\
Nil per os (excluding the first day of life), & $49(53.3 \%)$ \\
frequency (percentage) & $7(7.6 \%)$ \\
Retinopathy of prematurity, frequency (percentage) & $1(1.1 \%)$ \\
Postngen on day 28 of life, frequency (percentage) & $4(4.3 \%)$ \\
Necrotizing enterocolitis & \\
\hline
\end{tabular}

\section{Growth}

The mean birth weight was $867 \mathrm{~g}(\mathrm{SD}=81.4)$ with a mean birth weight Z-score of $-0.45(\mathrm{SD}=1.01)$ and $-0.72(\mathrm{SD}=$ 1.20) as per Fenton Growth Chart and Intergrowth 21st Project newborn weight charts respectively. Table 3 displays the mean birth weight Z-score, weight Z-score at
36 weeks and delta Z-score as per the Fenton Growth Chart and Intergrowth 21st Project growth standard. The mean percentage weight loss was $7.38 \%(\mathrm{SD}=5.82)$ and the mean number of days to regain birth weight was 18.2 days $(S D=10.2)$. Mean weight velocity was $13.5 \mathrm{~g} / \mathrm{kg} /$ day $(\mathrm{SD}=3.1)$ for the full length of hospital stay. At 36 weeks postmenstrual age, the mean weight for males was $1494 \mathrm{~g}$ $(\mathrm{SD}=297)$ with a mean weight Z-score of $-2.81(\mathrm{SD}=$ 1.16) and - $3.18(\mathrm{SD}=1.84)$ as per Fenton Growth Chart and Intergrowth 21st Project growth standard respectively. Among females, at 36 weeks the mean weight was $1569 \mathrm{~g}$ $(\mathrm{SD}=201)$ with a mean weight $\mathrm{Z}$-score of $-2.21(\mathrm{SD}=$ 1.02) and - $1.95(\mathrm{SD}=1.36)$ as per Fenton Growth Chart and Intergrowth 21st Project growth standard respectively. An independent samples t-test showed a significant difference in mean weight Z-scores between birth and 36 weeks postmenstrual age, $p<0.001$. This was true for both reference growth charts. Therefore, infants were significantly lighter for postmenstrual age at 36 weeks compared to the time of birth. Table 4 shows how growth parameters varied across different birth weight categories.

Table 3 shows that a statistically significant increase in infants labeled as small for gestational age was observed with the Intergrowth 21st Project growth standard compared to the Fenton Growth Chart. There was a larger number of infants who plotted above the 10th centile on the Intergrowth 21st Project standards compared to the Fenton Growth Chart, but this was not statistically significant. There was no statistically significant difference between the Z-scores derived from Fenton Growth Chart and Intergrowth 21st standard for birth weight, weight at 36 weeks and delta $Z$ score.

Figures 1 and 2 shows how the mean weekly weight for females and males respectively markedly differed from both the Fenton Growth Chart and Intergrowth 21st Project growth standards. Many infants who regained birth weight in 21 days or less did not have an adequate weight velocity afterwards and the vice versa is true as shown in Table 5. Only 25 infants $(27.2 \%)$ had good growth (regained their birth weight in 21 days or less and subsequently had a weight velocity above $15 \mathrm{~g} / \mathrm{kg} /$ day) (Table 5).

Table 3 Birth weight Z-score and endpoint outcomes at 36 weeks according to Fenton Growth Chart and Intergrowth 21 st Project standard. $P$ values expressing the difference between these charts are shown. Chi squared test used for the variables "small for gestational age" and "weight above $10^{\text {th }}$ centile at 36 weeks". Student t-test used for the variables "Delta Z-score", "Birthweight Z-score" and "Weight Z-score at 36 weeks"

\begin{tabular}{lllll}
\hline & Number of infants plotted & Fenton Growth Chart & Intergrowth 21st Project & $P$ value \\
\hline Small for gestational age, $\mathrm{n}(\%)$ & 89 & $13(14.6 \%)$ & $27(30.3 \%)$ & 0.012 \\
Birth weight Z-score, mean (SD) & 89 & $-0.45(1.01)$ & $-0.72(1.20)$ & $-2.57(1.72)$ \\
Weight Z-score at 36 weeks, mean (SD) & 89 & $-2.50(1.13)$ & $-1.87(1.30)$ & 0.107 \\
Delta Z-score, mean (SD) & 89 & $-2.05(0.87)$ & $20(22.5 \%)$ & 0.250 \\
Weight above 10th centile at 36 weeks, n (\%) & 89 & $11(12.4 \%)$ & 0.075 \\
\hline
\end{tabular}


Table 4 Birth weight categories and corresponding growth parameters. Weight velocity was calculated from the day birth weight was regained to 36 weeks postmenstrual age

\begin{tabular}{llllllll}
\hline Birth weight & $\begin{array}{l}\text { Total number } \\
\text { of infants }\end{array}$ & $\begin{array}{l}\text { Infants with good } \\
\text { growth (N/\%) }\end{array}$ & $\begin{array}{l}\text { Infants with discharge } \\
\text { weight > 10th centile } \\
\text { (N/\%) }\end{array}$ & $\begin{array}{l}\text { Median Gestational } \\
\text { age (min - max) }\end{array}$ & $\begin{array}{l}\text { Mean Delta Z-score } \\
\text { from birth to } \\
36 \text { weeks (SD) }\end{array}$ & $\begin{array}{l}\text { Mean number of } \\
\text { days to regain } \\
\text { birth weight (SD) }\end{array}$ & $\begin{array}{l}\text { Mean weight } \\
\text { velocity (SD) }\end{array}$ \\
\hline $600-699$ & 3 & $0(0 \%)$ & $0(0 \%)$ & $23(23-28)$ & $-2.8(0.7)$ & $10.6(9.2)$ & $11.6(2.0)$ \\
$700-799$ & 13 & $6(46.2 \%)$ & $2(15.4 \%)$ & $27(24-29)$ & $-2.1(0.9)$ & $14.7(7.4)$ & $14.0(3.6)$ \\
$800-899$ & 35 & $12(34.3 \%)$ & $4(11.4 \%)$ & $28(25-34)$ & $-2.0(0.8)$ & $19.7(9.4)$ & $14.0(3.3)$ \\
$900-999$ & 41 & $7(17 \%)$ & $5(12.2 \%)$ & $28(23-32)$ & $-2.2(1.3)$ & $18.5(11.3)$ & $13.0(2.8)$ \\
\hline
\end{tabular}

\section{Macronutrient intake during the first $\mathbf{2 8}$ days if life}

The mean number of days to reach full enteral feeds was 15.9 days $(\mathrm{SD}=6.3)$ and by the seventh day of life, enteral feeds contributed more than $50 \%$ of caloric intake. A plateau of $90-92 \%$ mean enteral caloric contribution was reached from the twentieth day. During the first 28 days of life, the mean number of days in which infants received at least $160 \mathrm{mls} / \mathrm{kg} /$ day of enteral feeds was 12.1 days $(S D=6.3)$. Thirty-four infants had an adequate caloric intake (above $110 \mathrm{kcal} /$ $\mathrm{kg}$ /day). Mean caloric intake during the first 28 days was $97.0 \mathrm{kcal} / \mathrm{kg} /$ day $(\mathrm{SD}=14.4)$. A mean caloric intake above $80 \mathrm{kcal} / \mathrm{kg} /$ day was reached on day 8 , by day 14 the mean caloric intake was above $110 \mathrm{kcal} / \mathrm{kg}$. There was a steady increase in mean weekly caloric intake from 65 , $7 \mathrm{kcal} / \mathrm{kg} /$ day $(\mathrm{SD}=18.7)$ in the first, $101 \mathrm{kcal} / \mathrm{kg} /$ day $(\mathrm{SD}=8.6)$ in the second, $118 \mathrm{kcal} / \mathrm{kg} /$ day $(\mathrm{SD}=5.0)$ in the third to $123 \mathrm{kcal} / \mathrm{kg} /$ day $(\mathrm{SD}=2.9)$ in the fourth week. The mean protein intake was $2.5 \mathrm{~g} / \mathrm{kg} /$ day $(\mathrm{SD}=0.7)$ with a mean daily intake above $3.0 \mathrm{~g} / \mathrm{kg} /$ day being reached on the twentieth day of life. The mean lipid intake was $4.4 \mathrm{~g} / \mathrm{kg} /$ day $(\mathrm{SD}=1.1)$ with a mean daily intake above $5 \mathrm{~g} / \mathrm{kg} /$ day being reached at the fourteenth day of life.

Pearson correlational analysis showed that during the first 28 days of life, weight velocity increased with a shorter duration to attain full feeds $(r=-0.38)$ and

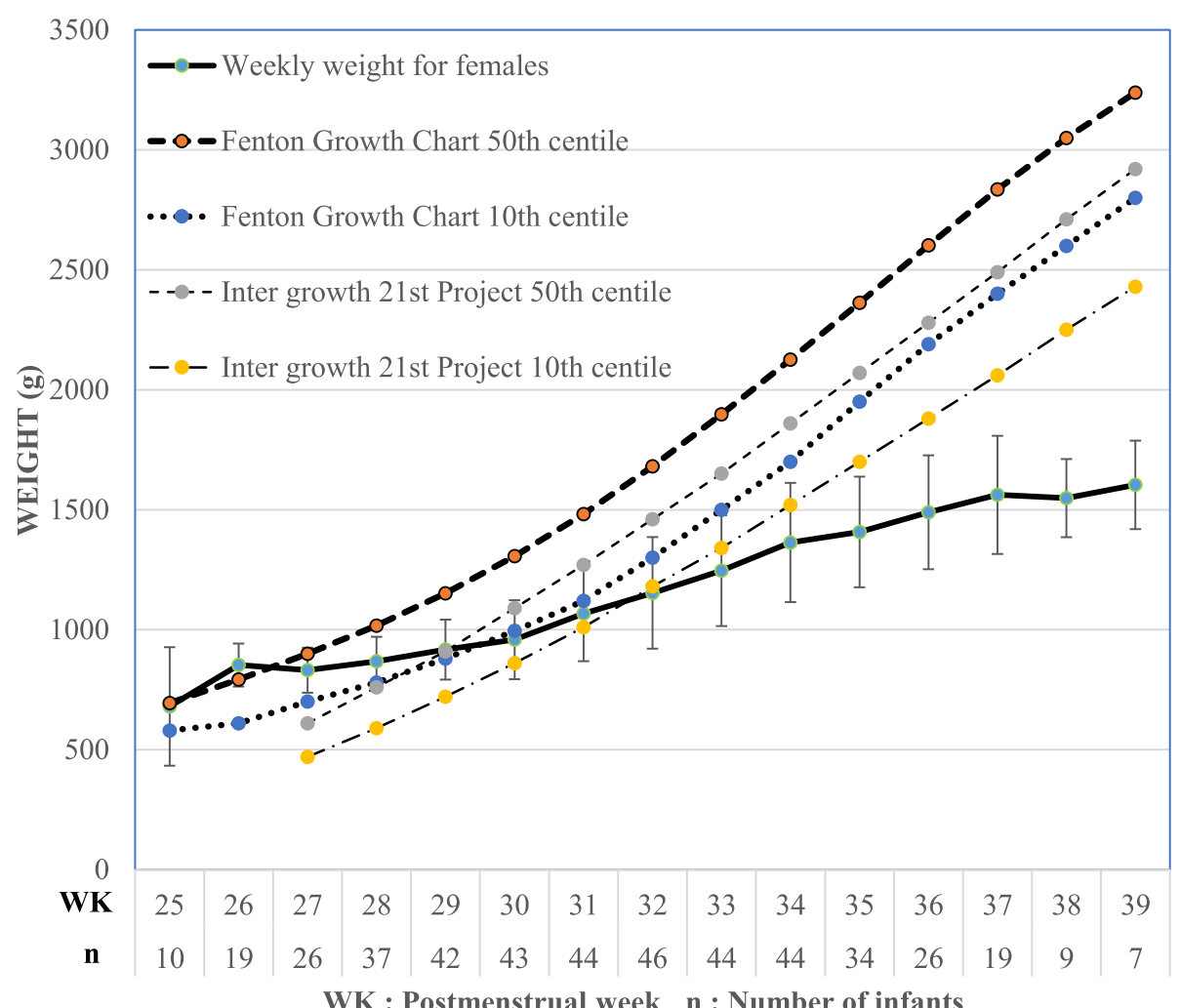

Fig. 1 Growth curve for females with standard deviation indicated for each mean weekly weight. Fenton Growth Chart and Intergrowth 21st Project centile lines shown as reference 


\section{0}

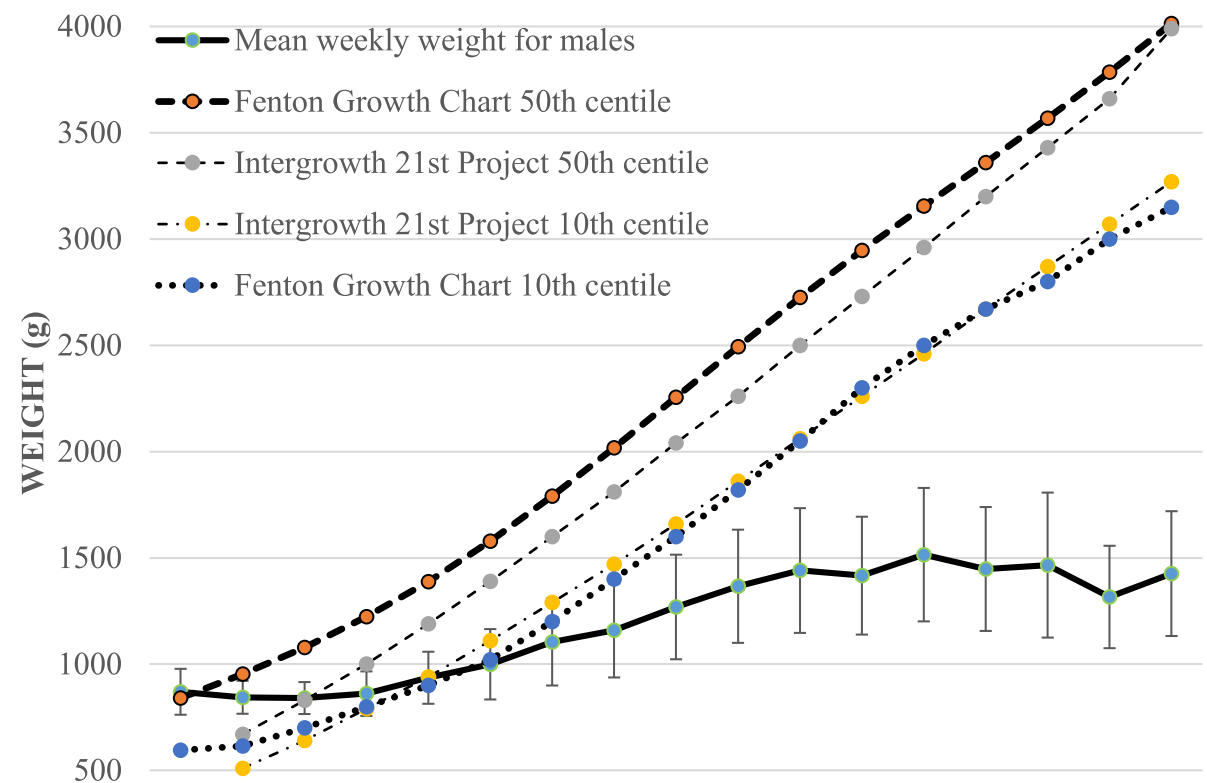

\begin{tabular}{r|c|c|c|c|c|c|c|c|c|c|c|c|c|c|c|c|c|}
$\mathbf{W K}$ & 26 & 27 & 28 & 29 & 30 & 31 & 32 & 33 & 34 & 35 & 36 & 37 & 38 & 39 & 40 & 41 & 42 \\
$\mathbf{n}$ & 7 & 14 & 21 & 26 & 32 & 40 & 40 & 42 & 43 & 39 & 36 & 25 & 19 & 12 & 8 & 5 & 5 \\
\multicolumn{10}{c|}{}
\end{tabular}

Fig. 2 Growth curve for males with standard deviation indicated for each mean weekly weight. Fenton Growth Chart and Intergrowth 21st centile lines shown as reference

the longer the infant remained on feeds of at least $160 \mathrm{mls} / \mathrm{kg} /$ day $(r=0.44)$. Increases in protein $(r=0.38)$, lipid $(r=0.42)$ and caloric intake $(r=0.38)$ were associated with an increase in weight velocity during the first 28 days of life.

\section{Complications of prematurity}

A comparison was done between the group classified as "good growth" $(n=25)$ and that classified as "poor growth" $(n=67)$. Complications of prematurity which showed a significant association with poor growth were CPAP for more

Table 5 Distribution of growth parameters (number of days to regain birth weight and weight velocity) among infants and the resultant discharge weight centile

\begin{tabular}{|c|c|c|c|c|}
\hline & $\begin{array}{l}\text { Weight velocity }>15 \mathrm{~g} / \mathrm{kg} / \\
\text { day, regained birth weight } \\
\text { in } 21 \text { days or less }\end{array}$ & $\begin{array}{l}\text { Weight velocity }>15 \mathrm{~g} / \mathrm{kg} / \\
\text { day, regained birth weight } \\
\text { after } 21 \text { days }\end{array}$ & $\begin{array}{l}\text { Weight velocity }<15 \mathrm{~g} / \mathrm{kg} / \\
\text { day, regained birth weight } \\
\text { in } 21 \text { days or less }\end{array}$ & $\begin{array}{l}\text { Weight velocity }<15 \mathrm{~g} / \mathrm{kg} / \\
\text { day, regained birth weight } \\
\text { after } 21 \text { days }\end{array}$ \\
\hline Number of infants & 25 & 6 & 34 & 27 \\
\hline $\begin{array}{l}\text { Infants with weight } \\
\text { > Fenton Growth } \\
\text { Chart 10th centile } \\
\text { at } 36 \text { weeks, N (\%) }\end{array}$ & $6(24 \%)$ & $2(33.3 \%)$ & $3(8.8)$ & $0(0 \%)$ \\
\hline $\begin{array}{l}\text { Infants with weight } \\
\text { > Intergrowth } 21 \text { st Project } \\
\text { 10th centile at } 36 \text { weeks, } \\
\text { N (\%) }\end{array}$ & $10(40 \%)$ & $3(50 \%)$ & $6(17.6 \%)$ & $1(3.7 \%)$ \\
\hline $\begin{array}{l}\text { Mean weight velocity, } \\
\mathrm{g} / \mathrm{kg} / \text { day (SD) }\end{array}$ & $16.6(1.4)$ & $17.5(2.1)$ & $12.1(1.9)$ & $11.5(2.6)$ \\
\hline $\begin{array}{l}\text { Mean number of days to } \\
\text { regain birth weight, days (SD) }\end{array}$ & $14.6(5.0)$ & $24.3(2.1)$ & $10.8(7.0)$ & $29.4(7.1)$ \\
\hline
\end{tabular}


Table 6 Neonatal characteristics associated with poor growth. Univariate analysis with Chi-squared test or Fischer's exact used as appropriate

\begin{tabular}{|c|c|c|c|c|c|}
\hline Variable & & Poor growth & Good growth & $\mathrm{n}$ & $P$-value \\
\hline \multirow[t]{2}{*}{$\overline{\mathrm{PDA}}$} & Yes & $13(100 \%)$ & $0(0 \%)$ & 13 & 0.017 \\
\hline & No & $54(68.4 \%)$ & $25(31.6 \%)$ & 79 & \\
\hline \multirow[t]{2}{*}{ Sepsis after day 3 of life } & Yes & $45(84.9 \%)$ & $8(15.1 \%)$ & 53 & 0.002 \\
\hline & No & $22(56.4 \%)$ & $17(43.6 \%)$ & 39 & \\
\hline \multirow[t]{2}{*}{ Invasive ventilation } & Yes & 16(94.1\%) & $1(5.9 \%)$ & 17 & 0.034 \\
\hline & No & $51(68.0 \%)$ & $24(32.0 \%)$ & 75 & \\
\hline \multirow[t]{2}{*}{ CPAP more than 2 days } & Yes & $26(89.7 \%)$ & $3(10.3 \%)$ & 29 & 0.014 \\
\hline & No & $41(65.1 \%)$ & $22(34.9 \%)$ & 63 & \\
\hline \multirow[t]{2}{*}{ Nil per os (excluding the first day of life) } & Yes & 49(80.3\%) & $12(19.7 \%)$ & 61 & 0.023 \\
\hline & No & 18(58.1\%) & 1341.9\%) & 31 & \\
\hline \multirow[t]{2}{*}{ Oxygen on day 28 of life } & Yes & $54(79.4 \%)$ & $14(20.6 \%)$ & 68 & 0.017 \\
\hline & No & $13(54.2 \%)$ & $11(45.8 \%)$ & 24 & \\
\hline
\end{tabular}

than 2 days, invasive ventilation, oxygen on day 28 of life, late-onset sepsis, PDA and being kept nil per os (excluding the first day of life) (Table 6). No single complication of prematurity was independently associated with neither a weight above the 10 th centile at 36 weeks nor a significant difference of delta Z-score between birth and 36 weeks when the Fenton Growth Chart was used. However, use of the Intergrowth 21st Project growth standards showed a significant difference in delta Z-score between infants who were receiving oxygen by day $28(p=0.024)$, those with PDA $(p=0.001)$ and sepsis after day $3(p=0.050)$ compared to those who did not have such complications. Being kept NPO $(p=0.123)$, receiving for CPAP more than 2 days $(p=0.069)$, antenatal steroids $(p=0.219)$ and invasive ventilation $(p=0.254)$ did not show a significant difference in delta Z-scores compared to those who did not have such complications. A Chi squared test showed a significant association between infants having a weight at 36 weeks less than the 10th centile and those who had sepsis after day 3 of life when the Intergrowth 21 st Project growth standards were used $(p=0.021)$.

\section{Discussion}

This study details the pathological growth pattern in ELBW infants leading to an undesirable weight at 36 weeks postmenstrual age. In the present study, infants regained birth weight in 18.3 days and had a mean weight velocity of $13.5 \mathrm{~g} / \mathrm{kg} /$ day. Although a recommendation on the minimum acceptable weight velocity does not exist [24], the mean weight velocity in the present study was comparable to previous studies $[11,12]$ and approaches the frequently used minimum of $15 \mathrm{~g} / \mathrm{kg} /$ day [24]. The present study shows that many infants who regained birth weight in 21 days or less did not have an adequate weight velocity afterwards and vice versa. This resulted in failure of most infants to attain a weight above the 10th centile at 36 weeks on both the Fenton Growth Chart and Intergrowth 21st Project Postnatal Chart. Findings by Dejhalla et al. among 21 ELBW infants with an uncomplicated hospital stay showed much better outcomes with $71 \%$ of infants having a weight above the 10th centile on discharge [25]. The study excluded infants with blood culture proven sepsis, necrotizing enterocolitis and neonatal surgery among other complications. This highlights the importance of identifying the neonatal characteristics associated with growth.

The mean caloric intake in the present study is comparable to previous studies but lags in protein intake $[6,25]$. Indeed, during the first few days of life, infants in the present study had a more rapid advancement of caloric intake and enteral feeds compared to the study by Dejhalla et al. whose infants had a better outcome. The determining factor could have been the protein intake, in the study by Dejhalla et al., a protein intake of $3.0 \mathrm{~g} / \mathrm{kg} /$ day was reached by the tenth day compared to the twentieth day in the present study.

CPAP duration exceeding 2 days, invasive ventilation, oxygen on day 28, late-onset sepsis, being kept nil per os and PDA were associated with poor growth (number of days to regain birth weight and weight velocity). In a South African study by Mudahemuka et al., the growth of 69 VLBW infants who survived to discharge from the neonatal unit was reviewed. In the study, a growth velocity $<14 \mathrm{~g} / \mathrm{kg} /$ day was associated with antenatal steroids and the number of days nil per os without ITN correlated negatively with the discharge weight Z-score [11]. In the present study, no association was demonstrated between growth and antenatal steroids, however the definition of good growth velocity was different from that use by Mudahemuka et al. Alejandro et al. demonstrated multiple neonatal characteristics associated with 
a significant decline in Z-score from birth to discharge including mechanical ventilation and PDA among 130 infants with a birth weight less than $1500 \mathrm{~g}$ [26]. These findings approximate the results of the present study, however, the use of discharge weight Z-score as an endpoint by Alejandro et al. presents a possibly significant difference in study design.

In the present study, a greater portion of infants were considered small for gestation age using the Intergrowth 21st Project growth standards compared to the Fenton Growth Chart. The increase in number of infants plotting above the 10th centile at 36 weeks using the Intergrowth 21st standards approaches statistical significance. These findings are consistent with a study conducted by Funda et al. on 248 infants in Turkey comparing the Fenton Growth Chart to Intergrowth 21st Project standards [27]. Funda et al. did not find any increased risk for early morbidity in the new small for gestational age infants identified by the Intergrowth 21st Project growth standards. However, in the present study, although no neonatal factors were associated with a weight $>10$ th centile at 36 weeks when the Fenton Growth Chart was used, this was not the case with the Intergrowth 21st Project growth standards. When Intergrowth 21st Project growth standards were used, the decline in Z-score from birth to 36 weeks was significantly larger among infants with PDA, sepsis after day 3 of life and those who remained on oxygen at day 28 of life. This suggests that Intergrowth 21st Project growth standards may provide a better association between growth and neonatal complications in our population compared to the traditionally used Fenton Growth Chart. This finding reverberates the concern that intrauterine growth may not be the appropriate standard for extrauterine growth in premature infants, furthermore, whether the Fenton Growth Chart is suitable for our population [17].

\section{Study limitations}

This was a retrospective study and infants were managed as per attending physicians' discretion. The method by which gestational age was determined was not standardized. A larger sample would have allowed a better description of rare complications of prematurity and infants who attended follow-up clinic at 12 months corrected age as only a few infants were picked up. Thirtysix infants (40.4\%) were discharged before 36 weeks had their discharge weight Z-score analyzed as the one at 36 weeks, however, the resulting error was assumed to be small since the mean postmenstrual age at discharge was 36.7 weeks. Infants discharged before 36 weeks had a mean postmenstrual age of 34.5 weeks $(\mathrm{SD}=1.1)$ at the time of discharge.

However, this study provides a detailed description of macronutrient intake, such detail has rarely been described in South Africa and other middle and lowincome countries. The present study also explores the usefulness of the Intergrowth 21st Project growth standards compared with the traditionally used Fenton Growth Charts.

\section{Conclusion and recommendations}

The growth of ELBW infants at CMJAH is suboptimum. Multiple complications of prematurity are associated with poor growth and nutritional intake correlates positively with weight velocity. There is need for a multifaceted approach to address characteristics associated with poor growth. Respiratory complications of prematurity can be reduced by increased coverage of antenatal steroids. Infants are likely receiving NCPAP after a significant delay at $\mathrm{CMJAH}$ neonatal unit, there is a need to avail enough NCPAP units in the Transitional Unit. A protocol addressing both volume and nutritional requirements during initiation of enteral feeds is needed. Consideration should be given to start ITN by $24 \mathrm{~h}$ rather than the current $48 \mathrm{~h}$ in infants not on full enteral feeds. Small enteral feeds can also be introduced on the first day of life. Chorioamnionitis is likely underreported, more vigilant surveillance and treatment in pregnant mothers could prevent premature delivery. Strong consideration should be given for the use of Intergrowth 21st Project growth standards as reference for normal postnatal growth in premature infants instead of the Fenton Growth Chart currently in use. Unlike the Fentons Growth Charts, use of the Intergrowth 21st Project growth standards revealed the association between neonatal factors and poor growth. A large multicenter prospective study is needed to assess the extent to which changes brought about by the Intergrowth 21st Project growth standards correlate with long term outcomes.

\footnotetext{
Abbreviations

CMJAH: Charlotte Maxeke Johannesburg Academic Hospital; CPAP: Continuous positive airway pressure; ELBW: Extremely low birth weight (birth weight less than 1000 g); ITN: Intravenous total nutrition; NEC: Necrotising enterocolitis; RDS: Respiratory distress syndrome; REDCAP: Research electronic data capture; ROP: Retinopathy of prematurity; VLBW: Very low birth weight (birth weight less than $1500 \mathrm{~g}$ )
}

\section{Acknowledgments}

None.

Authors' contributions

TM conceptualized and designed the study, collected data and carried out the data analysis, drafted the initial manuscript and approved the final manuscript. DEB conceptualized and designed the study, assisted with data analysis, reviewed and revised the manuscript, and approved the final manuscript. TR conceptualized and designed the study, reviewed and revised the manuscript, and approved the final manuscript. 


\section{Availability of data and materials}

The datasets used during the current study are available from the corresponding author on reasonable request.

\section{Ethics approval and consent to participate}

Ethics approval for this study was granted by the Human Research Ethics Committee (HREC) of the University of the Witwatersrand. This was a retrospective study, the need for consent to participate was waived.

\section{Consent for publication}

Not applicable.

\section{Competing interests}

The authors declare that they have no competing interests.

Received: 24 December 2018 Accepted: 3 June 2019

Published online: 11 July 2019

\section{References}

1. Horbar JD, Badger GJ, Carpenter JH, Fanaroff AA, Kilpatrick S, LaCorte M, et al. Trends in mortality and morbidity for very low birth weight infants, 1991-1999. Paediatrics. 2002;110(1):143-51.

2. Niklasson A, Engström $E$, Hård A-L, Wikland KA, AJPr H. Growth in very preterm children: a longitudinal study. Pediatr Res. 2003;54:899-905.

3. Saigal S, Stoskopf BL, Streiner DL, Burrows EJP. Physical growth and current health status of infants who were of extremely low birth weight and controls at adolescence. Pediatrics. 2001;108:407-15.

4. Kelleher KJ, Casey PH, Bradley RH, Pope SK, Whiteside L, Barrett KW, et al. Risk factors and outcomes for failure to thrive in low birth weight preterm infants. Pediatrics. 1993:91(5):941-8.

5. Embleton NE, Pang N, Cooke RJJP. Postnatal malnutrition and growth retardation: an inevitable consequence of current recommendations in preterm infants? Pediatric. 2001;107(2):270-3.

6. Stephens BE, Walden RV, Gargus RA, Tucker R, McKinley L, Mance M, et al. First-week protein and energy intakes are associated with 18-month developmental outcomes in extremely low birth weight infants. Pediatrics. 2009:123(5):1337-43.

7. Sowande OA, Ogundoyin OO, Adejuyigbe OJSP. Pattern and factors affecting management outcome of neonatal emergency surgery in lle-lfe, Nigeria. Surg Pract. 2007;11(2):71-5.

8. Chaudhari S, Kadam S. Total parenteral nutrition in neonates. Indian Pediatr. 2006;43(11):953.

9. Neu J. Gastrointestinal development and meeting the nutritional needs of premature infants. Am J Clin Nutr. 2007:85(2):629S-34S.

10. Mackay CA, Ballot De Fau - Cooper PA, Cooper PA. Growth of a cohort of very low birth weight infants in Johannesburg, South Africa. BMC Pediatr. 2011;11:50.

11. Mudahemuka JC, Ballot D. Birth weight recovery among very low birth weight infants surviving to discharge from Charlotte Maxeke Johannesburg Academic Hospital. S Afr J Child Health. 2014;8(4):149-53.

12. Lango MO, Horn AR, Harrison MC. Growth velocity of extremely low birth weight Preterms at a tertiary neonatal unit in South Africa. J Trop Pediatr. 2013:59(2):79-83.

13. Harris PA, Taylor R, Thielke R, Payne J, Gonzalez N, Conde JG. Research electronic data capture (REDCap) — a metadata-driven methodology and workflow process for providing translational research informatics support. J Biomed Inform. 2009;42(2):377-81.

14. Patel AL, Engstrom JL, Meier PP, Kimura RE. Accuracy of methods for calculating postnatal growth velocity for extremely low birth weight infants. Pediatrics. 2005;116(6):1466-73.

15. Fenton TR, Kim JH. A systematic review and meta-analysis to revise the Fenton growth chart for preterm infants. BMC Pediatr. 2013;13(1):59.

16. Villar J, Ismail LC, Victora CG, Ohuma EO, Bertino E, Altman DG, et al International standards for newborn weight, length, and head circumference by gestational age and sex: the newborn cross-sectional study of the INTERGROWTH-21st project. Lancet. 2014;384(9946):857-68.

17. Villar J, Giuliani F, Bhutta ZA, Bertino E, Ohuma EO, Ismail LC, et al. Postnatal growth standards for preterm infants: the preterm postnatal follow-up study of the INTERGROWTH-21st project. Lancet Glob Health. 2015;3(11):e681-e91.

18. Battaglia FC, Lubchenco LO. A practical classification of newborn infants by weight and gestational age. J Pediatr. 1967;71(2):159-63.
19. Mimouni FB, Lubetzky R, Yochpaz S, Mandel D. Preterm Human Milk macronutrient and energy composition: a systematic review and metaanalysis. Clin Perinatol. 2017:44:1557-9840 Electronic.

20. Bell MJ, Ternberg JL, Feigin RD, Keating JP, Marshall R, Barton L, et al. Neonatal necrotizing enterocolitis. Therapeutic decisions based upon clinical staging. Ann Surg. 1978;187(1):1.

21. Agarwal K, Jalali S. Classification of retinopathy of prematurity: from then till now. Community Eye Health. 2018;31(101):S4

22. Kindler A, Seipolt B, Heilmann A, Range U, Rudiger M, Hofmann SR. Development of a diagnostic clinical score for hemodynamically significant patent ductus arteriosus. Front Pediatr. 2017;5:280

23. Hossain $M$, Islam M, Shahidullah M, Akhter H. Pattern of change of weight following birth in the early neonatal period. Mymensingh Med J. 2006;15(1):30-2.

24. Goldberg DL, Becker PJ, Brigham K, Carlson S, Fleck L, Gollins L, et al. Identifying malnutrition in preterm and neonatal populations: recommended indicators. J Acad Nutr Diet. 2018;118(9):1571-2.

25. Dejhalla M, Lahage N, Parvez B, Brumberg HL, La Gamma EF. Early postnatal growth in a subset of convalescing extremely-low-birthweight neonates: approximating the "index fetus" ex utero. J Pediatr Gastroenterol Nutr. 2015;61(3):361-6.

26. Avila-Alvarez A, Solar Boga A, Bermúdez-Hormigo C, Fuentes Carballal J. Extrauterine growth restriction among neonates with a birthweight less than 1500 grams. An Pediatr (English Edition). 2018;89(6):325-32.

27. Tuzun F, Yucesoy E, Baysal B, Kumral A, Duman N, Ozkan H. Comparison of INTERGROWTH-21 and Fenton growth standards to assess size at birth and extrauterine growth in very preterm infants. J Matern Fetal Neonatal Med. 2018;31(17):2252-7.

\section{Publisher's Note}

Springer Nature remains neutral with regard to jurisdictional claims in published maps and institutional affiliations.
Ready to submit your research? Choose BMC and benefit from:

- fast, convenient online submission

- thorough peer review by experienced researchers in your field

- rapid publication on acceptance

- support for research data, including large and complex data types

- gold Open Access which fosters wider collaboration and increased citations

- maximum visibility for your research: over $100 \mathrm{M}$ website views per year

At BMC, research is always in progress.

Learn more biomedcentral.com/submissions 